\title{
Hazard and Risk of Highway Maintenance Works: Case Study of PLUS Expressways
}

\author{
Asmalia Che Ahmad ${ }^{1, a}$, Ida Nianti Mohd Zin ${ }^{1}$, Mohamad Nasrin Rosli ${ }^{1}$, Abdul Muhaimin Ab Wahid ${ }^{1}$, and Izatul Farrita Mohd \\ Kamar $^{1}$ \\ ${ }^{1}$ Faculty of Architecture, Planning and Surveying, Universiti Teknologi Mara (Perak), Seri Iskandar, Malaysia
}

\begin{abstract}
The North- South Expressway (NSE) (Lebuhraya Utara-Selatan) is the longest expressway in Malaysia with the total length of about $772 \mathrm{~km}$ (482 miles) running from Bukit Kayu Hitam in to Johor Bahru. It is known named after the highway's concessionaire, Projek Lebuhraya Utara Selatan Berhad (North South Expressway Project) abbreviated as PLUS Expressway. A study on the occupational safety among maintenance workers of PLUS Expressway was conducted. The aim for this research is to identify the hazards and determine the risk level of highway maintenance works. This research has identified the hazards occupies during highway maintenance works. Subsequently, the levels of risk for hazards during highway maintenance works are determined. The scope of this study is along the northern PLUS Expressway specified from Southern Ipoh to Bukit Kayu Hitam and focused on the maintenance workers of Projek Penyelenggaraan Lebuhraya Berhad (PROPEL). Eighty (80) sets of questionnaires survey on likelihood and severity of highway maintenance hazards have been distributed to highway maintenance workers. The data were analysed by using Excel to compose weightage average index (WAI) in order to compute the risk level of those hazards. The result concluded that the extreme level of hazard that occurred during maintenance of highway are hazards related to electricity, hazards that engage with scaffolding, hazards while using crane and hazards involve fire and explosion.
\end{abstract}

\section{Introduction}

The North- South Expressway Project (NSE) or Projek Lebuhraya Utara Selatan Berhad (North South Expressway Project) abbreviated as PLUS Expressway. (Lebuhraya Utara-Selatan) is the longest expressway in Malaysia. The total length of PLUS Expressway about 772 $\mathrm{km}$ (482 miles) running from Bukit Kayu Hitam in to Johor Bahru [1]. It passes 7 states i.e. Johor, Melaka, Negeri Sembilan, Selangor, Perak, Penang and Kedah. This expressway links many major cities and town thus acting as backbone to economic development of western Peninsular Malaysia. Significantly, this infrastructure service reduces travelling time and faster alternative route between various locations.

Proper maintenance is essential for reliable and smooth operation of highway in order to maintain its function as a key infrastructure that serve as network to the nation. Improper maintenance works would increase hazards that lead to accidents associated with human, damage of property and environment as well as boosting the operational cost. Study by Ganapthy (2010) showed that highway maintenance worker lives are in high risk where most accidents cases at work zone of highway involved them [2]. Therefore, safety for highway maintenance workers is crucial since the maintenance workers are put into the work zone of highway to conduct the maintenance task.

Hence, a study on the occupational safety among maintenance workers of PLUS Expressway was conducted. The objectives for this study are to identify the hazards and determine the risk level of highway maintenance works. This study focused on the maintenance workers of Projek Penyelenggaraan Lebuhraya Berhad (PROPEL) who responsible on maintenance task along the northern PLUS Expressway specified from Southern Ipoh to Bukit Kayu Hitam.

\section{Highway Maintenance}

\subsection{PLUS Expressway}

The North-South Expressways is widely known for its running length of the west coast of Peninsular Malaysia from Bukit Kayu Hitam near the border of Thailand in the north to Johor Bahru on the border of Singapore in the south, including the Senai to Johor Bahru stretch to the Kempas Spur Road with a full length of expressways about 772 kilometers [1]. It is the only expressway served the major cities along west coast of Peninsular Malaysia, In addition, PLUS Expressway is also providing other links to other principal roadways, which included the Penang Bridge, the Malaysia-Singapore Second Crossing,

\footnotetext{
${ }^{\mathrm{a}}$ Corresponding author: asmalia809@perak.uitm.edu.my
} 
the Federal Highways, the North-South Expressway Central Link and the Sistem Lingkaran-Lebuhraya Kajang Sdn. Bhd. (SILK Highway).

PLUS Expressway is selected for this study since it represents the most in highway maintenance works. PLUS Expressway operation of maintenance include 70 $\mathrm{km}$ dual three-lane and $715 \mathrm{~km}$ dual two-lane expressway of with approximately $10 \%$ and $90 \%$ each of the overall expressways length. Moreover, there are also 61 toll plazas, 64 interchanges, 296 bridges and 2 tunnels that need diverse methods of maintenance. Additionally maintenance also include 2 overhead bridge restaurants, 18 rest and service areas (RSA), 47 lay-bys, 244 billboards a well as other ancillary facilities [1].

\subsection{Maintenance of Highway}

Maintenance is defined as work in order to keep, restore or improve every part of building or facilities, to maintain building performance and its services including the surroundings, as well as to sustain the utility and value of the building. It includes improvement, refurbishment, upgrading and repair works to the existing facilities according to a currently accepted standard [3]. Maintenance consists of actions directed toward maintaining a social system in a serviceable state [4]. According to British Standard (2010) EN 13306:2010, maintenance is combination of all technical, administrative and managerial actions during the life cycle of an item intended to retain it in, or restore it to, a state in which it can perform the required functions [5].

Maintenance can be categorized into two types which are preventive maintenance and corrective maintenance [6]. Preventive maintenance is maintenance carried out at predetermined intervals or according to prescribed criteria and intended to reduce the probability of failure or the degradation of the functioning of an item. The preventive maintenance action is performed on condition based or predetermined maintenance. Corrective maintenance is maintenance carried out after fault recognition and intended to put an item into a state in which it can perform a required function. The corrective maintenance action is carried out based on deferred or immediate maintenance.

Maintenance of highway and road are generally classified into three categories as following [4,6,7]:

\section{- Routine works.}

Routine works are maintenance works that are required to be carried out continuously and funded from recurring budget. These works can be grouped into cyclic and reactive works types. Cyclic works are undertaken base on maintenance standard frequency. Vegetation control, herbicides, verge cutting and culvert as well as other cleaning chores are examples of cyclic works. Reactive works, in the other hand are activities relate to intervention levels base on maintenance standard determine or when the maintenance is needed. An example of reactive work is patching which is carried out when the appearance of cracks or pot-holes on the road surfaces.

\section{- Periodic works.}

Periodic works are required at intervals of several years to preserve the structural integrity of the road and building. It also avoids deterioration condition of roads and building structures. Periodic works can be clustered as preventive, resurfacing, turfing, grass seeding, overlay, pavement reconstruction, plumbing, power and lighting, CCTV and perimeter security, erosion control, line marking as well as widening or realignment of roads. Periodic works are budgeted on a regular basis or included in the recurrent budget.

\section{- Special works.}

Special works are immediate or unplanned task that required maintenance activities. These works are not estimated in advance and usually performed ad hoc. This special works include emergency and unforeseen task such as removal of obstacles that are hazards to highway users for example fallen trees or branches, landslides, flash floods, soil heaps and windblown sand. Other special works include slope rehabilitation and stabilisation, clearing of debris, repair landslides and washouts. A contingency allowance is normally included within the recurrent budget to fund these special works.

According to Mohamed (2010) the primary goal of highway maintenance is maintaining the roads in a circumstance that turns to a good service and maximum safety to the travelling highway users [4]. This is accomplished by preserving the road free of disconcerting physical defects such as potholed pavements, broken pavement edges, free ravel, sticks surfaces, light and defective bridge decks and other imperfections. Moreover, building and structure also hold out longer with proper, continuous and efficient maintenance works. Poor maintenance may result the need for preparation, renovation or reconstruction that increase in cost the life cycle of the project [4].

\subsection{Highway maintenance worker}

A highway maintenance worker is the person who ensures that the highways and roads stay in safe, clean and useable. There are variety task of highway maintenance worker including regular maintenance, repair operations and fixing defects to highway and its surrounding facilities. This job demand physical strength and most of working time are spent outdoors. In addition, the highway maintenance worker face hazardous situations such as working along stretches of road with vehicle travelling at high rates of speed, operating works in unpredictable weather conditions as well as using with various machineries, tools and heavy equipment in daily task [8].

Consequently, the main duties and tasks of a highway maintenance worker are to [9]:

- Carry out maintenance and repairs to the highway to remain the roads and surrounding safe and clean.

- Install, maintain and work within temporary traffic management (using traffic lights, cones and barriers) to keep the traffic flow safe.

- Carry out repairs on all road categories and types laying new or replacement surfaces to specification. 
- Locate underground services for example gas and power cables and work safely around them.

- Work with a wide range of hand / power tools and plant to repair potholes, cut, replace and reinstate pavements / kerbs, lay new surfaces and excavate materials.

- Able to read technical information in order to understand what works needs to be completed.

- Apply appropriate health, safety and environmental procedures to avoid injury and incidents.

\subsection{Hazard and risk in highway maintenance work}

A hazard is referred to potential harm that causes damage or adverse health [10]. Hazard is any unsafe condition or possible root of an undesirable event with potential for impairment or damage [11]. Hazard is closed relationship with the risk. Risk is a measurement to analyse and evaluate the hazard [10]. The measurement is made by identification on how severe and when likely of the hazard. In other words, the risk assessment is an in-depth look to specify situations, process and other harmful activities or hazard at workplace.

The highway maintenance is a hazardous workplace due to the condition of works that are expose to movement of vehicle, unpredictable weather condition, surrounding and environment disaster as well as close contact to usage of various instrument, machinery and equipment [12]. The top five workplace hazards that have been discovered by OSHA (2010) are [13]:

- Electricity - one of the greatest hazard for worker who expose to power line task at workplace

- Excavation and trenching - the most recorded fatalities at site operation

- Scaffolding - the most common accident during construction and maintenance work

- Falls - the most dangerous accident that causes from slipping, tripping, falling objects and unstable work platforms

- Heavy equipment - main accident cause of struck by, collision, overloading, overturning

\section{Research Method}

This research was conducted according to basic of safety procedure which is hazard identification and risk survey in order to assess the risk of highway maintenance works.

\subsection{Hazard identification}

Hazard identification was the first objective of the research. Hazards during highway maintenance works were identified base on published article and safety reports by safety related authorities. Eight hazards were identified in this research. There are hazards involving scaffolding, crane and heavy equipment, vehicle and machinery, fire and explosion, excavating work, installation work, welding work and electricity.

\subsection{Risk survey}

The second objective is to determine the risk level for each hazard identified. Risk can be presented in variety of ways to communicate the level of risk for each hazard. Technically, risk value is calculated by multiplying frequency of hazards occurrence or likelihood with consequences or severity of hazards occurrence [14]. The outcome matrix enables to determine level of risks for each hazard at workplace.

Risk can be calculated using the following formula [15]:

$$
\text { Risk }(\mathrm{R})=\text { Likelihood }(\mathrm{L}) \times \text { Severity }(\mathrm{S})
$$

Survey on likelihood and severity of the hazards was obtained through primary data collection using questionnaire. Table 1 and 2 shows the scale used in determining likelihood and severity of hazard occurrence.

Table 1. Scale for likelihood of hazards [16].

\begin{tabular}{|c|l|c|}
\hline LIKELIHOOD & \multicolumn{1}{|c|}{ DESCRIPTION } & SCALE \\
\hline Almost Certain & $\begin{array}{l}\text { The most likely result of } \\
\text { the hazard or event }\end{array}$ & 5 \\
\hline Likely & $\begin{array}{l}\text { Has a good chance of } \\
\text { occurring and is not } \\
\text { unusual }\end{array}$ & 4 \\
\hline Possible & $\begin{array}{l}\text { Might be occur at } \\
\text { sometime in the future }\end{array}$ & 3 \\
\hline Unlikely & $\begin{array}{l}\text { Has not been known to } \\
\text { occur after many years }\end{array}$ & 2 \\
\hline Rare & $\begin{array}{l}\text { In particular impossible } \\
\text { and has never occurred }\end{array}$ & 1 \\
\hline
\end{tabular}

Table 2. Scale for severity of hazards [16].

\begin{tabular}{|c|l|c|}
\hline SEVERITY & \multicolumn{1}{|c|}{ DESCRIPTION } & SCALE \\
\hline Fatal & $\begin{array}{l}\text { Large number of fatalities } \\
\text { and/or major long-term } \\
\text { impact }\end{array}$ & 5 \\
\hline Major & $\begin{array}{l}\text { Fatalities and/or major } \\
\text { short-term impact }\end{array}$ & 4 \\
\hline Moderate & $\begin{array}{l}\text { Serious injuries and/or } \\
\text { significant impact }\end{array}$ & 3 \\
\hline Minor & $\begin{array}{l}\text { Minor injuries and/or short- } \\
\text { term impact }\end{array}$ & 2 \\
\hline Insignificant & $\begin{array}{l}\text { First aid injuries only and/or } \\
\text { minimal impact }\end{array}$ & 1 \\
\hline
\end{tabular}

The scope for this research is the highway maintenance workers for PLUS Expressway focusing on northern region. The northern region PLUS Expressway route is from Southern Ipoh $\mathrm{km} 274.0$ to Bukit Kayu Hitam $\mathrm{km} \mathrm{0.0.} \mathrm{These} \mathrm{highway} \mathrm{maintenance} \mathrm{worker} \mathrm{are}$ managed by Projek Penyelenggaraan Lebuhraya Berhad or PROPEL. The population of PROPEL northern region maintenance workers is 364 . Based on the population, the sample size of determined for this survey was 80 highway maintenance workers with $\pm 10 \%$ (e)precision [17].

Accordingly, eighty (80) sets of questionnaires 
survey on likelihood and severity of highway maintenance hazards have been distributed to highway maintenance workers. The distribution was done during their monthly briefing on highway maintenance task with assistance by the manager in charge. The data from the questionnaire survey were analysed by using Excel to compose weightage average index (WAI) in order to compute the risk level of those hazards.

\subsection{Risk assessment matrix}

In order to determine the risk level, the risk assessment matrix has to be resolve. The computations of the risk assessment matrix in order to attain the risk level consist of following steps:

1. Calculation of weightage average index (WAI) for likelihood of hazards

2. Calculation of weightage average index (WAI) for severity of hazards

3. Calculation of risk (WAI likelihood x WAI severity) of hazard
4. Determination of risk assessment matrix (Table 3) and risk level (Table 4)

The weightage average index is calculated based on the formula as below [18] :

Weightage Average Index $($ WAI $)=\sum \frac{\text { wi fi }}{\sum \text { fi }}$

where:

wi $=$ assigned weight for a particular class under 5-point likert scale

fi $=$ corresponding frequency of that particular class

$\mathrm{i}=1,2,3,4,5$ that illustrated 5-point likert scale according to specific context

The computation of WAI for each hazard was interpreted by schedule of risk assessment matrix (Table 3 ) and the indication of risk level in Table 4.

Table 3. Schedule of risk assessment matrix [15].

\begin{tabular}{|c|c|c|c|c|c|}
\hline \multirow{2}{*}{$\begin{array}{c}\text { LIKELIHOOD OF } \\
\text { HAZARDS }\end{array}$} & \multicolumn{5}{|c|}{ SEVERITY OF HAZARDS } \\
\cline { 2 - 6 } & INSIGNIFICANT (1) & MINOR (2) & MODERATE (3) & MAJOR (4) & FATAL (5) \\
\hline RARE (1) & 1 & 2 & 3 & 4 & 5 \\
\hline UNLIKELY (2) & 2 & 4 & 6 & 8 & 10 \\
\hline POSSIBLE (3) & 3 & 6 & 9 & 16 & 15 \\
\hline LIKELY (4) & 4 & 8 & 12 & 20 & 25 \\
\hline ALMOST CERTAIN (5) & 5 & 10 & 15 & & 12 \\
\hline
\end{tabular}

Table 4. Indication of risk level [15].

\begin{tabular}{|c|c|}
\hline \multicolumn{2}{|c|}{ RISK LEVEL } \\
\hline 1 to 2 & LOW \\
\hline 3 to 6 & MEDIUM \\
\hline 7 to 12 & HIGH \\
\hline More than 12 & EXTREME \\
\hline
\end{tabular}

\section{Result and findings}

Table 5 shows the demographic information of the respondent where $30 \%$ of the respondents have less than 5 years of experience. Similarly $30 \%$ of the respondents have experience between 6 to 10 years. $11.3 \%$ had experience between 11 to 15 years while 12.5 with $16-20$ years of experience. $16.2 \%$ of the respondent has more than 20 years of experience. Overall majority of the respondent $(70 \%)$ had less more than five years of working experience. These demonstrate that this group of respondent are reliable with pertinent experience to participate in this survey on hazards and risk of highway maintenance works.
Table 5. Working experience of respondent

\begin{tabular}{|l|c|c|}
\hline Working experience & Frequency & $\begin{array}{c}\text { Percentage } \\
(\mathbf{\%})\end{array}$ \\
\hline$<5$ years & 24 & 30.0 \\
\hline 6-10 years & 24 & 30.0 \\
\hline 11-15 years & 9 & 11.3 \\
\hline 16-20 years & 10 & 12.5 \\
\hline$>20$ years & 13 & 16.2 \\
\hline Total & 80 & 100.0 \\
\hline
\end{tabular}

By referring to Table 6 , majority $(57.5 \%)$ of the respondent had being involved in highway maintenance accident. This demonstrates that the highway maintenance 
workers are highly exposed to risk at their workplace.

Table 6. Respondent involved in highway maintenance accident

\begin{tabular}{|l|c|c|}
\hline $\begin{array}{c}\text { Involve in highway } \\
\text { maintenance accident }\end{array}$ & Frequency & $\begin{array}{c}\text { Percentage } \\
\text { (\%) }\end{array}$ \\
\hline Yes & 46 & 57.50 \\
\hline No & 34 & 42.50 \\
\hline Total & 80 & 100.00 \\
\hline
\end{tabular}

Eight hazards were identified in this research. The hazards are as the following:

1. Hazard involving scaffolding

2. Hazard involving crane and heavy equipment

3. Hazard involving vehicle and machinery
4. Hazard involving fire and explosion

5. Hazard involving excavating work

6. Hazard involving installation work

7. Hazard involving welding work

8. Hazard involving electricity

According to the survey and calculations of WAI and risk assessment matrix, the following result was obtained. The table 7 shows the WAI likelihood, WAI severity and risk assessment matrix for the eight types of highway maintenance hazards. The risk was calculated by multiplying likelihood with severity. Each figure of the risk was categorised into risk level (refer Table 4) and rank accordingly. Out of eight types of hazards studied, 4 hazards were classified under extreme risk while another four were in high risk. None of the hazards falls in either medium or low risk level.

Table 7. Summary of hazards and risk during highway maintenance works.

\begin{tabular}{|l|c|c|c|c|c|}
\hline \multicolumn{1}{|c|}{ Type of Hazard } & $\begin{array}{c}\text { Weightage } \\
\text { Average } \\
\text { index of } \\
\text { Likelihood }\end{array}$ & $\begin{array}{c}\text { Weightage } \\
\text { Average } \\
\text { index of } \\
\text { Severity }\end{array}$ & $\begin{array}{c}\text { Risk Assessment } \\
\text { Matrix }\end{array}$ & Risk level & Ranking \\
\hline Hazard involving electricity & 3.30 & 4.88 & $\mathbf{1 6 . 1 0}$ & Extreme & $\mathbf{1}$ \\
\hline Hazard involving scaffolding & 3.79 & 4.15 & $\mathbf{1 5 . 7 3}$ & Extreme & $\mathbf{2}$ \\
\hline $\begin{array}{l}\text { Hazard involving crane and heavy } \\
\text { equipment }\end{array}$ & 3.31 & 4.70 & $\mathbf{1 5 . 5 6}$ & Extreme & $\mathbf{3}$ \\
\hline Hazard involving fire and explosion & 2.91 & 4.28 & $\mathbf{1 2 . 4 5}$ & Extreme & $\mathbf{4}$ \\
\hline $\begin{array}{l}\text { Hazard involving vehicle and } \\
\text { machinery }\end{array}$ & 3.03 & 3.49 & $\mathbf{1 0 . 5 7}$ & High & $\mathbf{5}$ \\
\hline Hazard involving excavating work & 3.13 & 2.93 & $\mathbf{9 . 1 7}$ & High & $\mathbf{6}$ \\
\hline Hazard involving installation work & 3.16 & 2.74 & $\mathbf{8 . 6 6}$ & High & $\mathbf{7}$ \\
\hline Hazard involving welding work & 3.46 & 2.35 & $\mathbf{8 . 1 3}$ & High & $\mathbf{8}$ \\
\hline
\end{tabular}

The top rank of risk during highway maintenance works is hazards involving electricity which is 16.10 with status of extreme. Data from the U.S. Bureau of Labor Statistics (BLS) indicate that there were nearly 6,000 fatal electrical injuries to workers in the U.S. between 1992 and 2013 [19]. Electrical hazards can be divided into 2 groups which are primary and secondary [20]. Primary hazards such as flowing of current through human body can cause electric shock with a harmful effect on the internal organs and their proper function. The impact of a strong electromagnetic field when working near a powerful antenna of a mobile operator along the highway can produce harmful effects tissue and organ damage which are delayed in time. Another primary electrical hazard is application of a controlled electrical substance in contact with hot and harmful substances such as welding and cutting. The blinding flash of an electrical substance can cause temporary or permanent eye damage, hot air and metal vapours can cause severe burns, inhaling hot electrical products can seriously damage respiratory system by burning lungs and throat or result in poisoning. Secondary electricity hazards may trigger other hazards for instance sources of fire and explosion and sources of other secondary effects when the flow of current through the human body leads to tripping, slipping, falling and the like.

The second rank of extreme highway maintenance risk is hazard involving scaffolding with the risk matrix of 15.73. The scaffolding industry has put workers in hazardous working situation where 10,000 accident cases were reported each year [21]. Hazards associated with scaffolding can be categorised according to design of the scaffolding, construction of scaffolding, environment in which scaffolding located as well as the usage of scaffolding [22].

A significant hazard associated with scaffolding design is collapse of the structure. This may cause multiple fatalities. The design failures include incorrect design, unsuitable foundations, inadequate edge protection, decking and bracing, inadequate access and 
egress, unstable scaffolding and overloading. Numerous hazards also exist related to construction and dismantling of scaffolding. Worker may obtained injury during manual handing of equipment, crushed by moving or lifting object, defective tools and equipments, falling objects and fall from scaffolding. The surroundings and environment also create scaffolding hazards such as obstructed workplace, poor lighting, poor access, wet or slippery walkways, and existence of blind spot and vehicle of highway user colliding to the scaffolding structure. The ultimate scaffolding hazard associated is the usage. Most accidents occur during working on scaffolding due to impatient of worker, unqualified personnel, under influence of drugs or alcohol and bad habits.

The third top rank of extreme risk during highway maintenance work is hazards involving crane and heavy equipment which is 15.56. The three major hazards identified by Harman (2014) that arise regarding crane and heavy equipment operation are electrical hazards, overloading and materials falling [23]. Electrical hazards of crane or heavy equipment accidents are result of metal part of a crane unintentionally contact with a high voltage power line. This contact occurs when the crane is moving nearby or under energized power lines which can result multiple injuries and death. Whereas, overloading is subject to structural stresses that cause unalterable damage. Overloading is result of hoisting load beyond capacity, swinging or sudden drop of load, usage of defective components and incompetency crane operators. Other hazards involve crane and heavy equipment is materials falling. Material falls due to slings and attachment were not secured properly. Visual impairment, mechanical failure and incompetency operator can cause the material lifted to slip and crash.

The forth top rank of extreme risk is hazard involving fire and explosions. This hazard include majority of maintenance highway activities which carried out using flammable substances accidently catching fire and explode [24]. Working activities which involves using or creating chemicals, vapours, liquids, gases, solids or dusts that can readily burn or explode is hazardous. The effects of fire and explosion can be devastating in terms of lives lost, injuries, significant damage to property, pollute the environment and ruin the business community. Occasionally this hazards also directly interrelated to electrical as source of secondary effects.

\section{Conclusion}

Overall, all the highway maintenance hazards are within extreme and high risk. The top four extreme risks are works involve electricity, scaffolding, crane and heavy equipment as well as fire and explosion. Nevertheless, other hazards with of high risk status such as hazard involving vehicle and machinery, excavation, installation and welding in highway maintenance works should also given serious attention. Action and control measures could be taken to maintain a good working condition and operation of highway run smoothly with low risk to the workers. Additionally, person in charge of the task that involve extreme and high risk task during highway maintenance work should be well trained and competent to avoid accidents among highway maintenance workers.

\section{References}

1. PLUS (2014) North- South Expressway (NSE). Accessed from http://www.plus.com.my/index.php?option=com content\&view

2. Ganapthy, V. R., Subramaniam, S. K., Mohaamad Diah, A. B., Suaidi, M. K., Hamidon, A. H. (2010). Flagman and Risk Involved in Road Construction Site. International Journal of Sustainable Construction Engineering \& Technology.

3. Horner, R.M.W, El-Haram, M.A and Munns, A.K., (1997), "Building Maintenance strategy: a new management approach.” Journal Of Quality In Maintenance Engineering, Vol. 3, No. 4, pp 273-280.

4. Mohamed, N. W. (2010). Road Maintenance Management System: A Case Study At Public Work Department. Unpublished Master Thesis. Faculty of Civil Engineering, Universiti Teknologi Malaysia.

5. British Standard (2010) Maintenance Terminology EN 13306:2010. BSI Publication. UK

6. European Standard EN 13306, Maintenance terminology (2001), CEN, European Committee for Standardization, Belgium

7. Worldbank (2001). Road and Highways: Construction and Maintenance. Accessed from http://www.worldbank.org/transport/roads/con\& main.htm

8. Bureau of Labor Statistics (BLS) (2015) Highway Maintenance Workers. Accessed from www.bls.gov/oes/current/oes474051.htm

9. UK Roads Liaison Group (UKRLG) (2013) The Highway Infrastructure Asset Management Guidance. Accessed from http://www.highwaysefficiency.org.uk/efficiency -resources/asset-management/highwayinfrastructure-asset-management-guidance.html

10. Canadian Centre for Occupational Health and Safety (CCOHS) (2009). Health \& Safety Program: Risk Assessment. Accessed from http://www.ccohs.ca/oshanswers/hsprograms/risk assessment.html

11. Marhavilas, P. K., Koulouriotis, D. and Gemeni, V. (2010). Risk Analysis and Assessment Methodologist in the Work Sites: On a review, classification and comparative study of the scientific literature of the period 2000-2009. Journal of Loss Prevention in The Process Industries, Vol. 24, pp 477-523.

12. Pratt, S.G., Fosbroke, D. E., \& Marsh, S. M. (2001). Building Safer Highway Work Zones: Measures to Prevent worker Injuries From Vehicles and Equipment (DHHS (NIOSH) 
Publication No. 2001-128).

13. Occupational Safety \& Health Administration, United States Department of Labor (OSHA) (2010) Hazards - Young Workers. Accessed from

https://www.osha.gov/youngworkers/hazards.htm 1

14. Baradan S., Mumtaz, A. Usmen. (2006) Comparative Injury and Fatality Risk Analysis of Building Trades. Journal of Construction Engineering and Management 132:533-539

15. Department of Occupational Safety and Health Malaysia (DOSH) (2008) Guidelines For Hazard Identification, Risk Assessment And Risk Control (HIRARC)

16. Jeong K.-S., Lee K.-W., Lim H.-K. (2010) Risk assessment on hazards for decommissioning safety of a nuclear facility. Annals of Nuclear Energy 37:1751-1762

17. Israel, G. D. (1992). Sampling the Evidence of Extension Program Impact Program Evaluation and Organizational Development, IFAS, University of Florida. PEOD-5. October.

18. Hermans, E., Ruan,D., , Brijs,T., Wets, G. and Vanhoof, K. (2010) Road Safety Risk Evaluation by means of Ordered Weighted Averaging Operators and Expert Knowledge. Accessed from https://uhdspace.uhasselt.be/dspace/.../1/A1Q2nummer2\%5B1\%5D.pdf

19. National Fire Protection Association (NFPA) (2015) Occupational Injuries From Electrical Shock and Arc Flash Events. Fire Protection Research Foundation
20. International Social Security Association (ISSA) (2010), Guide for Risk Assessment in Small and Medium Enterprises - Hazards arising from Electricity.

21. Shafii H., Rahman Z. A. and Othman A. R., (2005). Kajian Pengurusan Keselamatan Pekerja Di Tapak Bina. Universiti Tun Hussein Onn Malaysia. Accessed from http://www.searchinpdf.com/

22. Worksafe (2014) Safety in scaffolding. Newzealand.govt.nz. Accessed from http://www.business.govt.nz/worksafe/informatio n-guidance/all-guidance-items/scaffolding-bestpractice-guideline-for-scaffolding-in-newzealand/section-2-safety-in-scaffolding/2.8hazard-identification-and-management $\# 2.8 .4$

23. Harman, K (2014) Overhead Crane Safety Three Major hazard and preventive measures. Spanco Inc. Accessed from http://www.spanco.com/blog/entry/overheadcrane-safetythree-major-hazards-andpreventative-measures

24. HSE (2014) Apprenticeship Standard - Highways Maintenance Skilled Operative Level 2. Crown copyright. Accessed from https://www.gov.uk/government/uploads/system/ uploads/attachment_data/file/384288/CONSTRU CTIONBB -

_Highways_MaintenanceSkilledOperative_L2__Final.pdf



